\title{
Penerapan Augmented Reality dalam Visualisasi Katalog Apartemen Berbasis Android
}

\author{
Citra Arum Sari, I Ketut Gede Darma Putra, I Putu Arya Dharmaadi \\ Program Studi Teknologi Informasi, Fakultas Teknik, Universitas Udayana \\ Bukit Jimbaran, Bali, Indonesia, telp. 0361701806 \\ e-mail: citrarum95@gmail.com, ikgdarmaputra@unud.ac.id, aryadharmaadi@unud.ac.id
}

\begin{abstract}
Abstrak
Apartemen menjadi hunian yang diminati masyarakat sehingga banyak dibangun oleh para pengembang properti. Pengembangan apartemen yang pesat menimbulkan persaingan dalam pemasaran, sehingga diperlukan cara pemasaran yang lebih inovatif untuk menarik pembeli. Penerapan teknologi augmented reality untuk membuat katalog apartemen menjadi lebih interaktif dapat menjadi solusi pemasaran apartemen yang inovatif. Penelitian yang dikembangkan berfokus pada penerapan Augmented Reality di katalog pemasaran apartemen dalam bentuk aplikasi berbasis Android. Denah apartemen pada katalog divisualisasikan melalui model 3-dimensi dengan penambahan informasi dan fitur-fitur yang interaktif. Aplikasi dikembangkan dengan marker dinamis. Aplikasi memiliki 3 scene yaitu Main Menu, About dan Panduan. Dua fitur utama pada aplikasi adalah tracking marker, yaitu fitur untuk mengenali marker dan rotate, fitur untuk memutar objek 3-dimensi secara 360 derajat. Aplikasi diujicobakan pada dua buah smartphone dengan spesifikasi berbeda. Hasil pengujian menunjukkan bahwa aplikasi telah berhasil mempermudah pengguna melihat visualisasi katalog tanpa mengunjungi apartemen asli.
\end{abstract}

Kata Kunci: apartemen, katalog, augmented reality, Android

\begin{abstract}
Apartment is a residential area that is in demand by people, therefore many property developers build residential towers in a wide-scale. The massive project of apartment building increases marketing competition between real estate market participants, hence an innovative breakthrough in marketing is needed. Application of augmented reality technology would be the innovative marketing solution by transforming a dull marketing catalog to be more attractive. This research focused on the application of Augmented Reality to the apartment marketing catalog in a form of Android app. Apartment room plans were visualized through 3-dimention models with information and interactive features added. The application developed with dynamic markers. There are three scenes in the app, those were Main Menu, About and Panduan. Two main features in the application are tracking marker, which is a feature for recognizing marker and rotate, a feature for rotating the 3-dimention object up to 360 degrees. The Android app had tested in two different specifications of smartphones. The test results show that the application has succeeded in making it easier for users to view catalog visualizations without visiting the original apartment.
\end{abstract}

Keywords: apartment, catalog, augmented reality, Android

\section{Pendahuluan}

Apartemen adalah hunian berupa ruang atau rangkaian ruang yang dilengkapi dengan fasilitas serta perlengkapan rumah tangga. Model hunian apartemen relatif banyak berada di kota-kota besar. Gaya hidup modern dan sempitnya lahan di perkotaan mempengaruhi masyarakat untuk tinggal di hunian vertikal yang berlokasi strategis dan desain minimalis [1]. Ketertarikan masyarakat terhadap apartemen dimanfaatkan pengembang properti dengan membangun kompleks-kompleks apartemen di beberapa kota besar di Indonesia. Kuartal pertama (Q1) tahun 2017 menunjukkan 2900 unit apartemen telah selesai dibangun di Jakarta, dan terdapat 5616 unit apartemen yang baru diluncurkan pada kuartal yang sama [2]. Pesatnya pembangunan apartemen memunculkan persaingan penjualan antar pengembang properti. Persaingan dalam menjual apartemen membuat pengembang properti berusaha memasarkan 
apartemen dengan baik. Pemasaran apartemen umumnya dilakukan oleh bagian pemasaran dengan membawa media berupa katalog apartemen. Katalog fisik sebagian besar hanya menampilkan informasi apartemen tanpa mampu berinteraksi dengan calon pembeli. Komunikasi menjadi kurang interaktif karena hanya berlangsung satu arah. Perkembangan teknologi informasi dan komunikasi dapat dimanfaatkan untuk meningkatkan interaktifitas katalog fisik apartemen, sehingga lebih menarik bagi calon pembeli. Teknologi yang dapat diterapkan salah satunya augmented reality atau AR. Teknologi AR mampu membuat manusia seolah-olah berinteraksi dengan benda-benda maya, sehingga menimbulkan ketertarikan tersendiri.

Teknologi augmented reality telah beberapa kali diteliti dan diterapkan menjadi sebuah aplikasi yang bermanfaat bagi masyarakat. Penelitian dari Pangestu dkk [3] merupakan salah satu contoh penerapan teknologi augmented reality untuk mempromosikan hunian hotel atau villa. "Augmented Reality Mobile Application of Balinese Hindu Temples: DewataAR" oleh Waruwu dkk [4] yang menerapkan teknologi augmented reality untuk mempromosikan obyek wisata Pura Tanah Lot di Pulau Bali. Pemanfaatan lain juga dilakukan melalui penelitian dari Sudana dkk [5] dengan membangun aplikasi yang menampilkan gerak dasar tari Bali dalam bentuk 3-dimensi.

Penelitian-penelitian yang telah dipaparkan menerapkan teknologi augmented reality dengan marker yang bersifat statis. Aplikasi katalog apartemen yang dikembangkan pada penelitian ini menerapkan AR dengan marker dinamis. Marker dinamis memberikan keuntungan berupa ukuran aplikasi lebih kecil karena marker disimpan di cloud, serta model 3-dimensi dapat diubah tanpa memodifikasi kode program.

\section{Metodologi Penelitian}

\subsection{Gambaran Umum Sistem}

Augmented Reality Katalog Apartemen merupakan aplikasi yang menampilkan gambar 3-dimensi mengenai detail informasi dari desain apartemen. Aplikasi ini memberikan sebuah informasi kepada pengguna mengenai detail dan desain kamar apartemen yang telah terdaftar pada katalog. Aplikasi ini menggunakan metode Marker-based yang memerlukan frame Marker sebagai objek yang dideteksi. Proses dan tahapan yang dilalui ditunjukkan dengan diagram alir pada Gambar 1.

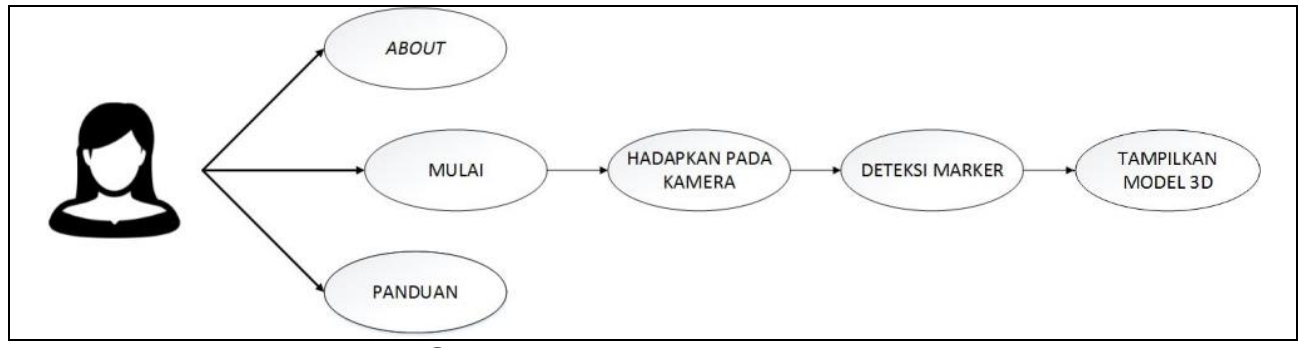

Gambar 1. Diagram Use case

Gambar 1 menunjukkan diagram use case dari rancangan sistem aplikasi katalog apartemen secara keseluruhan. Fitur-fitur yang terdapat pada aplikasi yaitu Main Menu, Halaman About, Halaman Panduan, dan Tracking Marker, dimana fitur Tracking Marker berfungsi untuk melakukan tracking terhadap marker yang menghasilkan output berupa tampilan model animasi 3-dimensi.

\subsection{Rancangan Sistem}

Tahapan yang selanjutnya harus dilakukan adalah perancangan sistem aplikasi, dimana pembuatan aplikasi ini perlu dicermati bagaimana menciptakan aplikasi yang mudah digunakan pengguna

a. Struktur Flowchart Aplikasi

Struktur flowchart berfungsi untuk mengilustrasikan alur kerja dari sistem, dan menjadi struktur dasar perancangan aplikasi. Struktur dapat dilihat pada Gambar 2. 


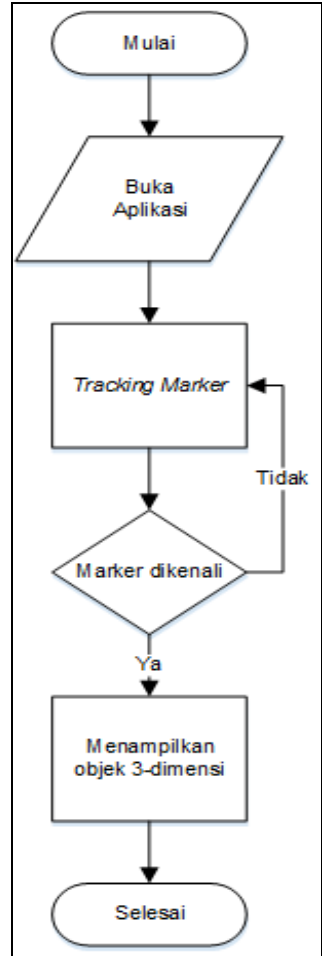

Gambar 2. Struktur Flowchart Aplikasi

Gambar 2 menunjukkan struktur flowchart aplikasi, disaat pengguna membuka aplikasi dan melakukan tracking atau pendeteksian marker, apabila marker dikenali maka sistem menampilkan objek 3-dimensi apartemen tepat di atas marker.

b. $\quad$ Activity Diagram Menu Tracking Marker

Activity diagram menggambarkan interaksi antara pengguna dengan sistem ketika masuk ke main menu aplikasi dan melakukan tracking marker. Gambar 3 merupakan activity diagram menu tracking marker.

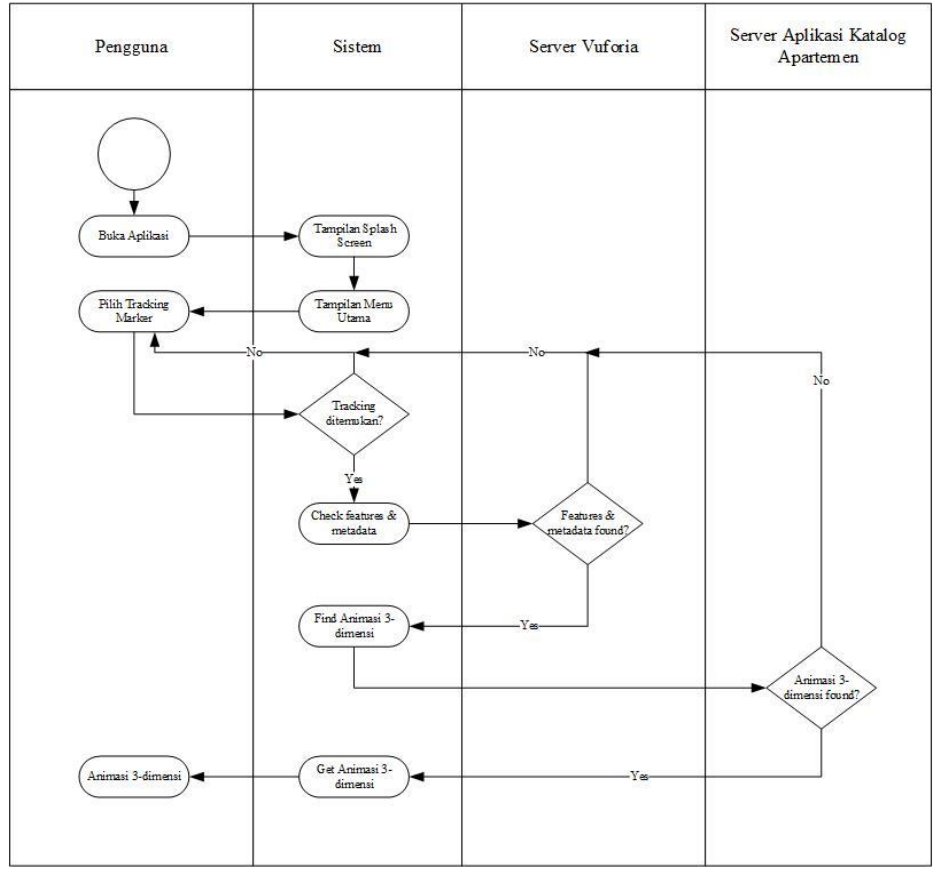

Gambar 3. Activity diagram tracking marker 
Gambar 3 menunjukkan diagram aktivitas antara pengguna dan sistem pada menu tracking marker. Pengguna membuka aplikasi dan memilih menu start, lalu mengarahkan kamera smartphone pada marker untuk dideteksi. Hasil tracking tersebut berupa feature marker. Sistem melakukan pengecekan marker pada Server Vuforia untuk mendapatkan metadata dari marker tersebut yang digunakan untuk mengambil animasi 3-dimensi dan informasi pada server local. Proses akhir dari fitur ini adalah pengguna dapat melihat tampilan animasi 3-dimensi.

\subsection{Rancangan Antarmuka}

Rancangan antarmuka adalah rancagan awal dari tampilan aplikasi katalog apartemen yang ditujukan untuk mempermudah pembuatan antarmuka dari sistem. Rancangan antarmuka aplikasi adalah sebagai berikut.

a. $\quad$ Rancangan Antarmuka Main Menu

Main Menu merupakan halaman yang yampil ketka pengguna membuka aplikasi katalog apartemen. Rancangan antarmuka Main Menu dapat dilihat pada Gambar 4.

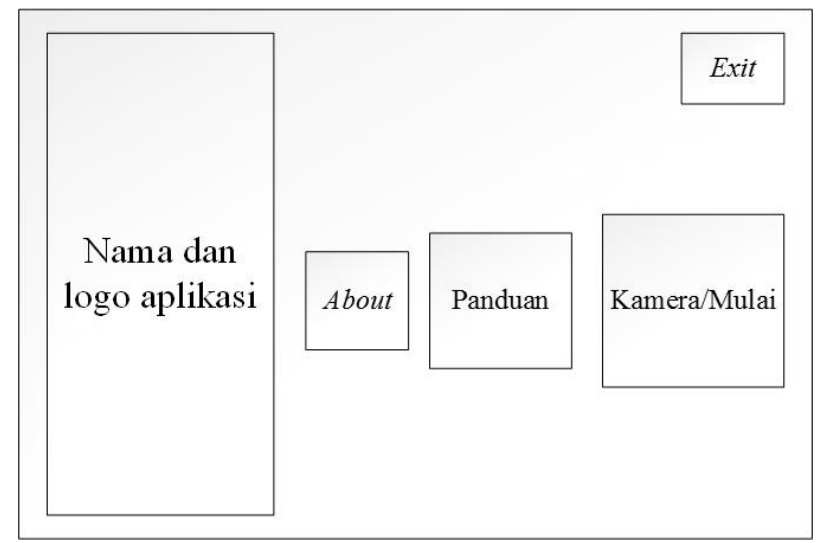

Gambar 4. Rancangan antarmuka Main Menu

Gambar 4 menunjukkan rancangan antarmuka Main Menu, dimana pengguna dapat melihat nama dan logo aplikasi, menu exit, tracking marker, about dan panduan.

b. Rancangan Antarmuka Halaman Tracking Marker

Halaman Tracking Marker merupakan halaman yang tampil ketika pengguna menekan tombol mulai. Rancangan antarmuka halaman Tracking Marker data dilihat pada Gambar 5.

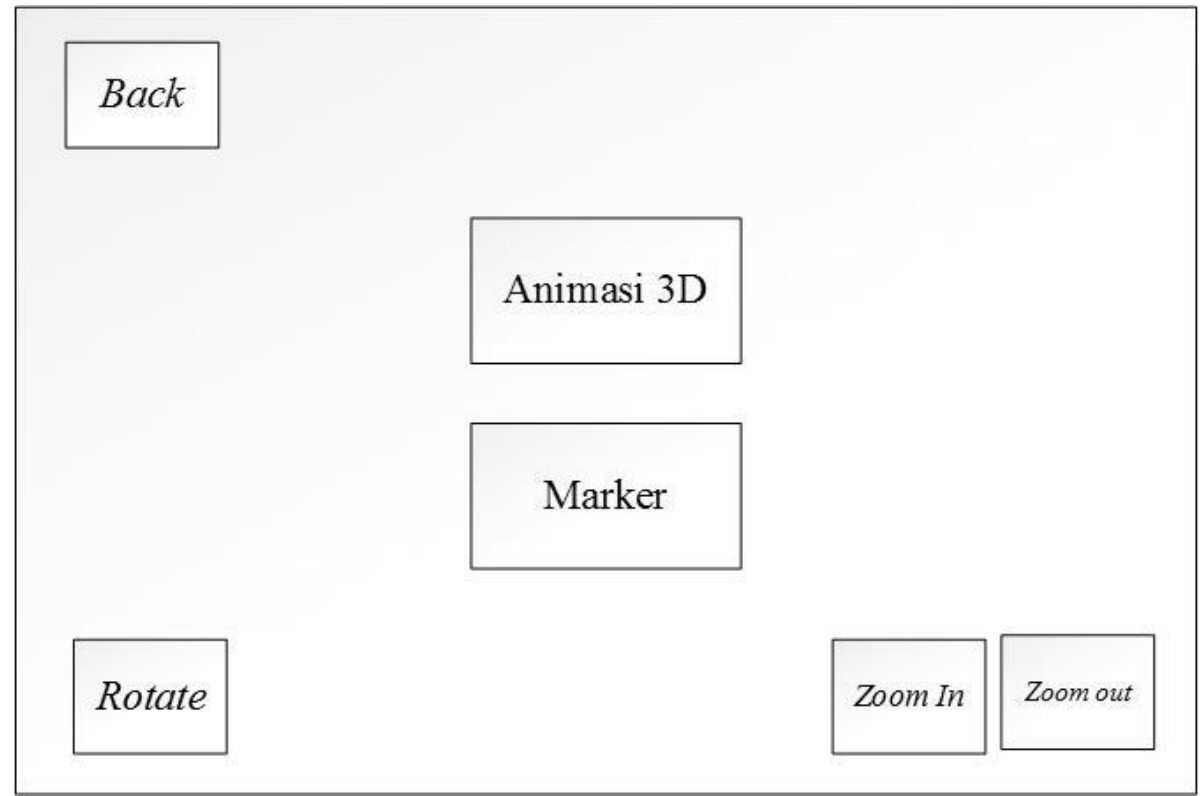

Gambar 5. Rancangan antarmuka halaman Tracking Marker 
Gambar 5 menunjukkan rancangan antarmuka halaman Tracking Marker, dimana pengguna dapat melakukan pendeteksian marker yang terdapat pada brosur.

\subsection{Perancangan Objek 3-dimensi Katalog Apartemen}

Perancangan objek 3-dimensi katalog apartemen adalah tentang perancangan model kamar yang terdapat pada katalog apartemen dalam bentuk 3-dimensi. Objek 3-dimensi dibuat menggunakan aplikasi Autodesk Maya. Tabel 1 menunjukkan hasil perancangan objek 3dimensi katalog apartemen.

Tabel 1. Daftar Model 3-dimensi

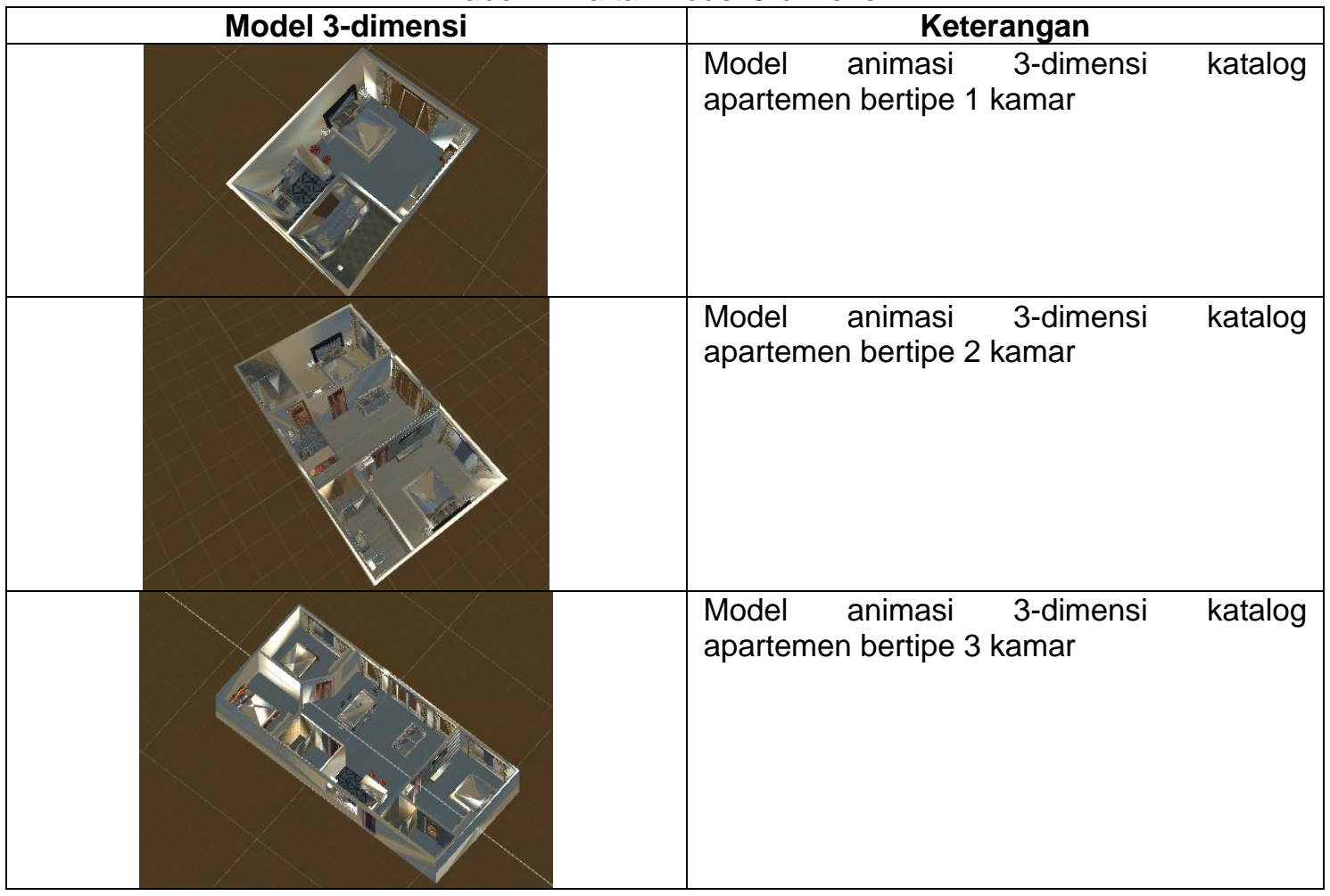

Objek 3-dimensi yang ada pada Tabel 1 ditunjukkan ketika pengguna menjalankan aplikasi. Objek 3-dimensi dapat menampilkan detail ruangan apartemen secara keseluruhan untuk setiap tipe apartemen. Masing-masing objek muncul sesuai dengan marker yang disorot ketika menggunakan aplikasi.

\subsection{Desain dan Pembuatan Brosur}

Brosur yang dibuat berfungsi sebagai media pemasaran, promosi dan media penempatan marker. Perancangan brosur dibuat menggunakan aplikasi Adobe Photoshop CS 6. Gambar 6 menunjukkan hasil perancangan brosur. 


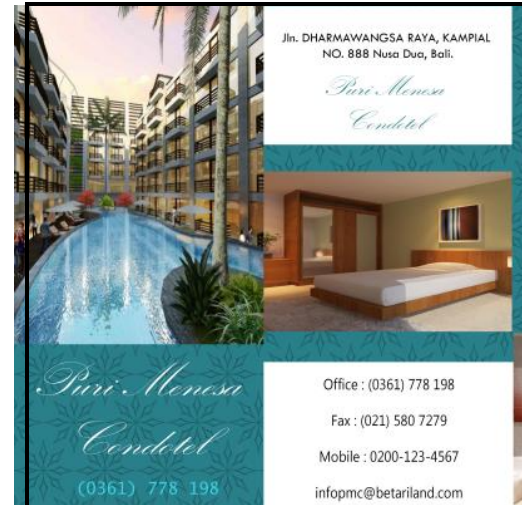

(a)
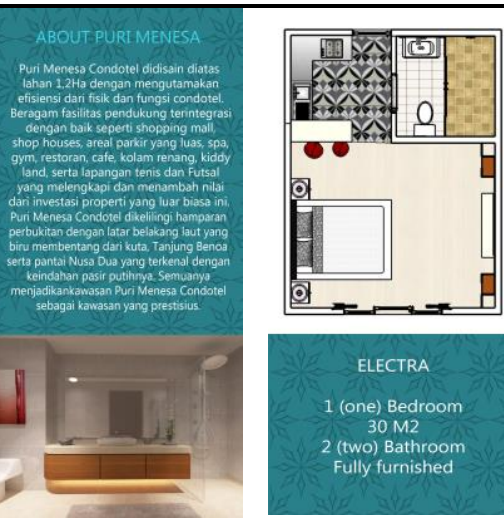

ELECTRA

(one) Bedroom

$30 \mathrm{M} 2$

2 (two) Bathroom
Fully furnished

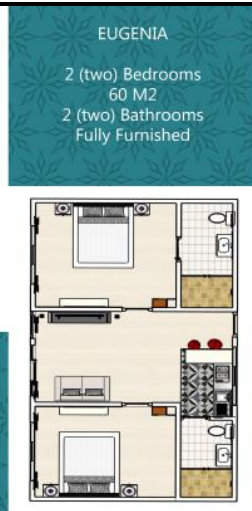

(b)

Gambar 6. (a) Hasil desain depan brosur, (b) Hasil desain belakang brosur

Gambar 6 (a) menunjukkan hasil pembuatan brosur tampak depan dan Gambar 6 (b) menunjukkan hasil pembuatan brosur tampak belakang yang juga berfungsi sebagai media penempatan marker.

\subsection{Desain dan Pembuatan Marker}

Vuforia memproses gambar yang digunakan sebagai marker untuk menghasilkan features. Gambar marker ditunjukkan pada Tabel 2.

Tabel 2. Daftar Marker

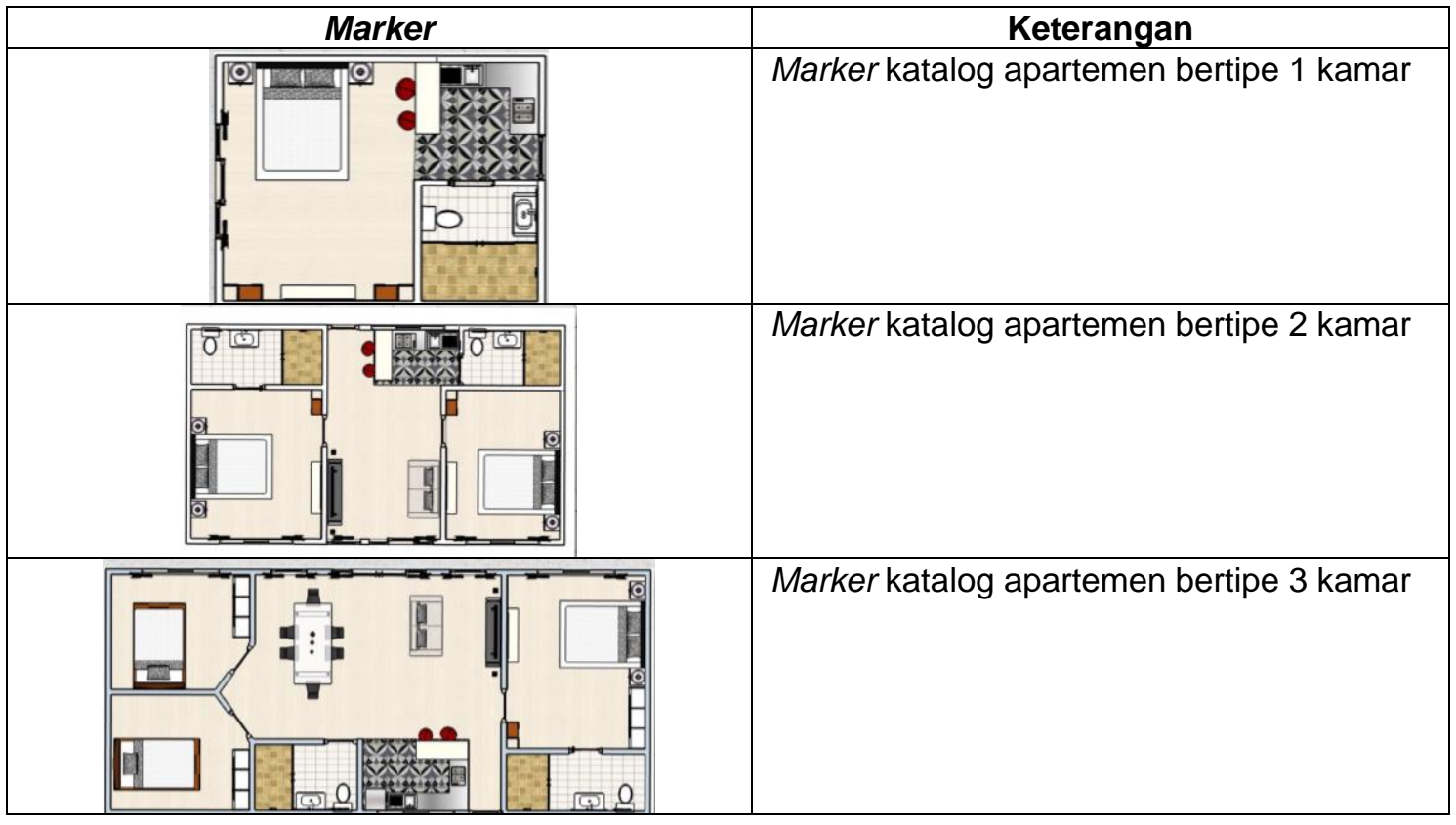

Tabel 2 menunjukkan hasil desain marker yang digunakan sebagai penanda untuk aplikasi Augmented Reality.

\section{Kajian Pustaka}


Kajian pustaka memuat materi yang menjadi referensi penelitian. Referensi yang dimuat yaitu tentang katalog pemasaran dan augmented reality. Kedua referensi untuk kajian pustaka dimuat dalam pembahasan 3.1 dan 3.2.

\subsection{Katalog Pemasaran}

Katalog pemasaran adalah salah satu bagian dari media pemasaran. Format penyajian katalog pada umumnya berbentuk lembaran kertas yang memuat informasi produk maupun jasa [6]. Perkembangan teknologi internet dan komunikasi membuat keterbatasan pemasaran menggunakan katalog mulai teratasi. Katalog dan internet dapat dipadukan dalam hal menciptakan e-marketing. Frasa e-marketing dapat diartikan sebagai cara baru dalam memasarkan sesuatu melalui jaringan internet dan jaringan komunikasi canggih lainnya. $E$ marketing tidak hanya terpaku pada internet, melainkan termasuk pemasaran melalui media komunikasi lain seperti telepon, intranet, ekstranet, dan lain-lain [7].

\subsection{Augmented Reality}

Augmented reality (AR) merupakan salah satu inovasi yang muncul dari perkembangan teknologi. Augmented reality adalah teknologi yang dapat membuat objek dua dimensi maupun tiga dimensi seakan-akan berada di dunia nyata dan dapat berinteraksi dengan manusia [8]. Teknologi augmented reality membantu menyederhanakan objek nyata dengan membawa objek maya, sehingga informasi dapat diterima oleh seluruh pengguna [9]. Objek virtual dalam augmented reality bersifat menambahkan, bukan menggantikan objek nyata [10]. AR mulai diaplikasikan ke dalam benda-benda yang dekat dengan keseharian manusia. Raksasa teknologi dunia mulai berinvestasi dalam pembangunan teknologi dan produk yang mengaplikasikan AR ke berbagai produk sehari-hari. Beberapa diantaranya adalah Microsoft yang meluncurkan Hololens, Google yang merilis aplikasi Tango, dan Apple yang menyatakan bahwa ARKit mereka merupakan platform AR terbesar di dunia [11].

\section{Hasil dan Pembahasan}

Penelitian yang dilakukan menghasilkan sebuah aplikasi Android bernama i-Apartment. Aplikasi dapat berfungsi pada smartphone dengan spesifikasi minimal Android KitKat. Aplikasi dapat digunakan sesuai fungsinya pada processor Dual-Core $2 \mathrm{GHz}$, kamera 8MP dan RAM 2GB. Marker aplikasi bersifat dinamis karena telah disimpan di server. Penerapan AR dengan marker dinamis mengakibatkan diperlukannya koneksi internet yang stabil ketika menjalankan aplikasi.

\subsection{Target Manager}

Marker dari aplikasi yang dikembangkan disimpan pada server Vuforia. Gambar target yang menjadi marker aplikasi disimpan dalam sebuah target manager. Seluruh marker harus didaftarkan ke dalam target manager terlebih dahulu, agar dapat ditampilkan pada aplikasi. Proses pendaftaran marker dimulai dengan pembuatan target manager. Pembuatan target manager dilakukan di server vuforia. Aplikasi i-Apartment memiliki target manager dengan tipe cloud karena marker tidak disimpan di perangkat, melainkan disimpan di server Vuforia. Gambar 7 menunjukkan proses pembuatan target manager aplikasi. 


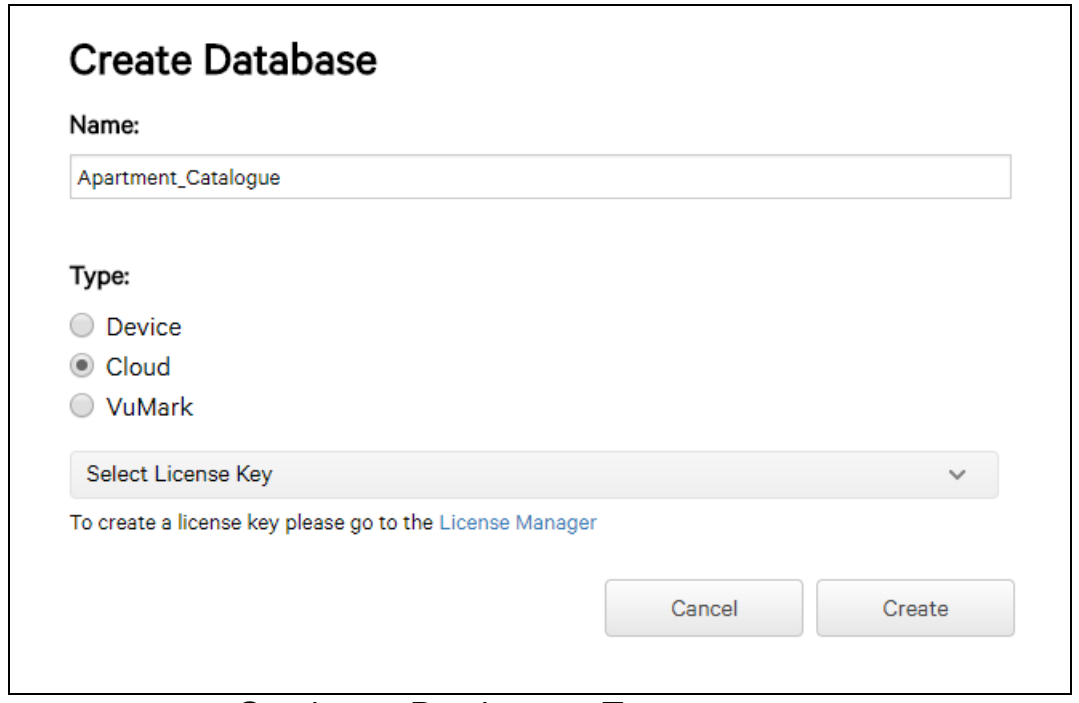

Gambar 7. Pembuatan Target manager

Target manager dapat diakses oleh aplikasi dengan autentikasi menggunakan kunci akses (access key). Kunci akses harus disertakan dalam proses pembuatan target manager. Target manager yang telah terdaftarkan dapat diisi dengan target. Gambar 8 menunjukkan proses unggah marker ke target manager.

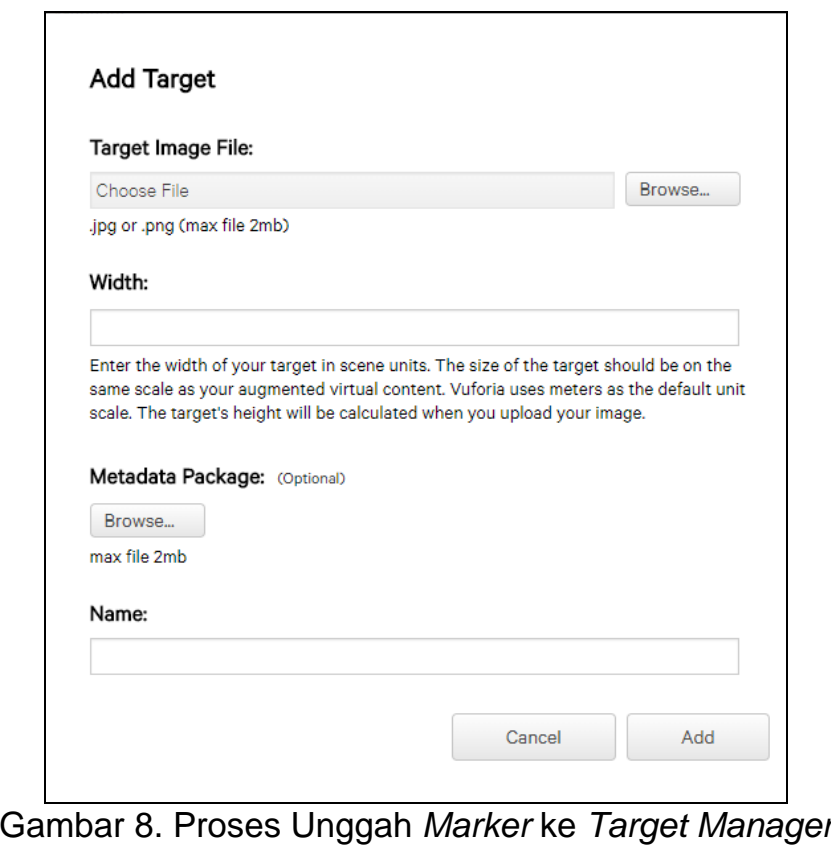

Target-target yang telah terunggah ke server Vuforia muncul pada tab Targets. Gambar 9 menunjukkan dua buah target yang telah diunggah ke target manager. Masing-masing target yang telah diunggah bernama roomone (marker untuk apartemen bertipe satu kamar) dan roomtwo (marker untuk apartemen bertipe dua kamar). 


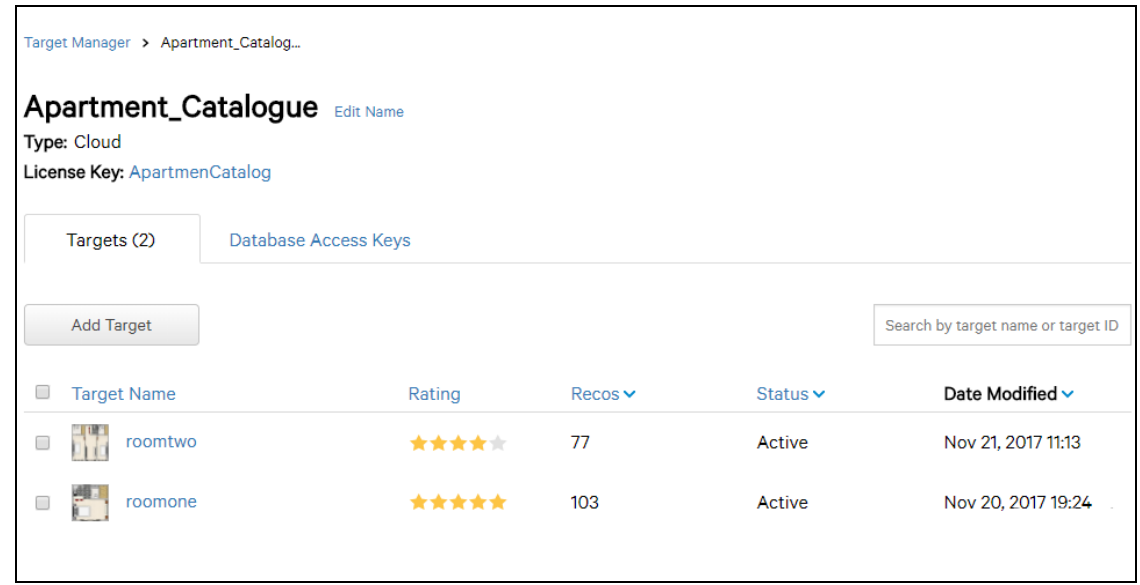

Gambar 9. Kumpulan Target

Setiap target memiliki ciri atau fitur yang ditambahkan secara otomatis oleh server Vuforia. Marker dapat dikenali berdasarkan fitur yang dimiliki. Jumlah fitur untuk masing-masing target ditunjukkan pada kolom rating di setiap target. Gambar 10 menunjukkan contoh fitur atau ciri yang terdapat pada target dengan judul roomtwo.

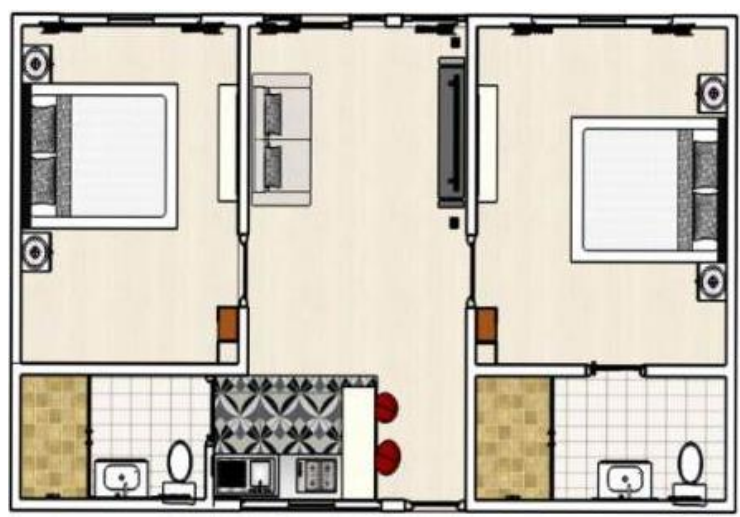

Gambar 10. Fitur Target roomtwo

Vuforia memberikan rating sebanyak 5 bintang untuk target roomone. Rating 5 bintang menunjukkan target roomone memiliki lima fitur unik yang dikenali. Jumlah fitur atau ciri yang ditambahkan oleh Vuforia menjadi panduan bagi aplikasi dalam mengenali marker.

\subsection{Uji Coba Aplikasi}

Uji coba dilakukan dengan menggunakan dua buah smartphone. Perangkat smartphone yang digunakan adalah Samsung Grand Neo Duos dan Samsung Galaxy S9. Spesifikasi kedua perangkat uji coba ditunjukkan pada Tabel 3.

Tabel 3. Spesifikasi Perangkat Pengujian Aplikasi

\begin{tabular}{|l|l|l|}
\hline \multicolumn{1}{|c|}{ Spesifikasi } & \multicolumn{1}{c|}{ Samsung Grand Neo Duos } & \multicolumn{1}{c|}{ Samsung Galaxy S9 } \\
\hline Sistem Operasi & Android Versi 4.1 (Jelly Bean) & Android Versi 8 (Oreo) \\
\hline Processor & Quad-Core 1.2 GHz, Cortex- & $\begin{array}{l}\text { Octa-core 2,7/2,8 GHz Quad } \\
+1,7 \mathrm{GHz} \text { Quad }\end{array}$ \\
\hline A7 & $1 \mathrm{~GB}$ & $4 \mathrm{~GB}$ \\
\hline RAM & $480 \times 480$ piksel & $2220 \times 1080$ piksel \\
\hline
\end{tabular}

Uji coba dilakukan terhadap tiga scene dan dua fitur utama aplikasi. Ketiga scene yang diujicobakan adalah scene main menu, scene about aplikasi, dan scene panduan penggunaan aplikasi. Dua fitur utama yang diujicobakan adalah fitur tracking marker dan fitur rotate.

Pengujian pertama dilakukan terhadap scene main menu. Kedua perangkat uji coba diuji dengan menampilkan scene main menu aplikasi. 


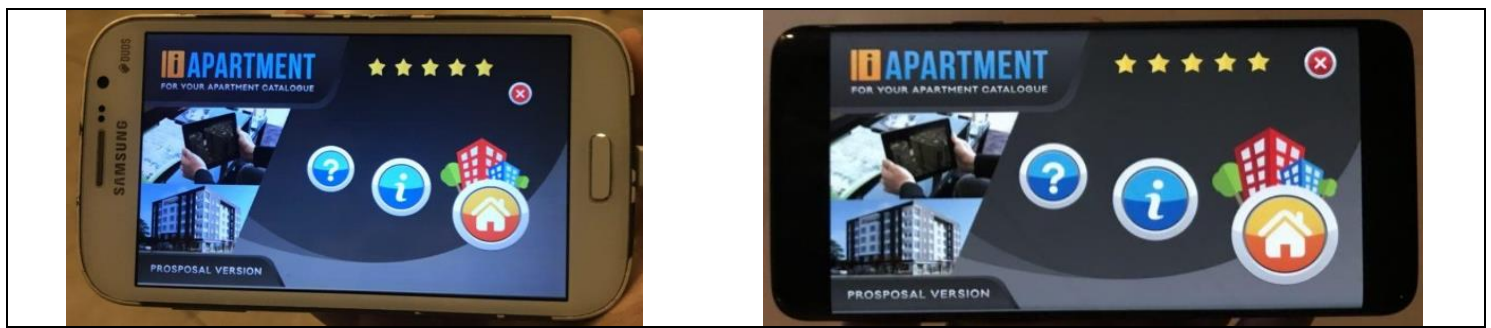

Gambar 11. Hasil Pengujian Scene Main menu pada Samsung Grand Neo Duos dan Samsung Galaxy S9

Gambar 11 menunjukkan hasil pengujian scene main menu dimana kedua perangkat berhasil menampilkan scene dengan proporsional. Pengujian kedua dilakukan terhadap scene about aplikasi.

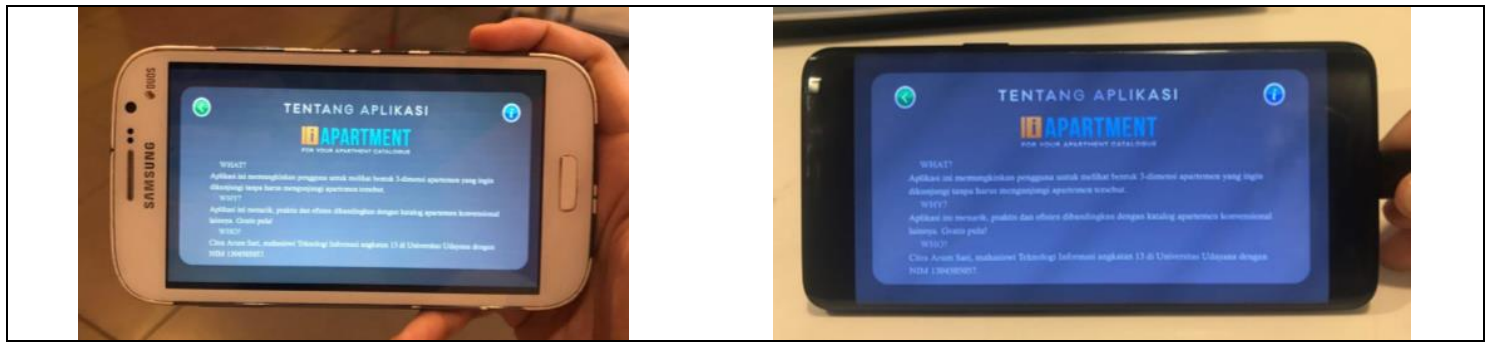

Gambar 12. Hasil Pengujian Scene About pada Samsung Grand Neo Duos dan Samsung Galaxy S9

Gambar 12 menunjukkan bahwa kedua perangkat dapat menampilkan scene about aplikasi dengan posisi gambar dan ikon aplikasi proporsional sesuai dengan resolusi layar masing-masing smartphone. Pengujian selanjutnya dilakukan terhadap scene panduan penggunaan aplikasi.

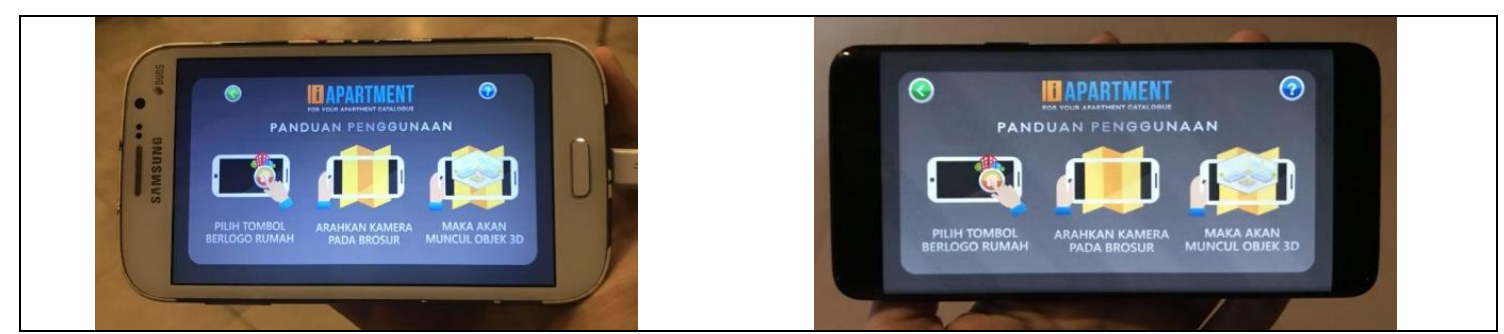

Gambar 13. Hasil Pengujian Scene Panduan pada Samsung Grand Neo Duos dan Samsung Galaxy S9

Gambar 13 menunjukan bahwa kedua perangkat dapat menampilkan scene panduan penggunaan aplikasi dengan posisi ikon dan gambar menyesuaikan resolusi kedua perangkat. Pengujian fitur dilakukan untuk menguji fungsi dari fitur aplikasi pada setiap perangkat. Fitur pertama yang diuji adalah tracking marker. Fitur tracking marker berguna untuk mendeteksi marker dan menampilkan gambar 3-dimensi. Gambar 14 menampilkan hasil pengujian fitur tracking marker pada kedua perangkat uji. 


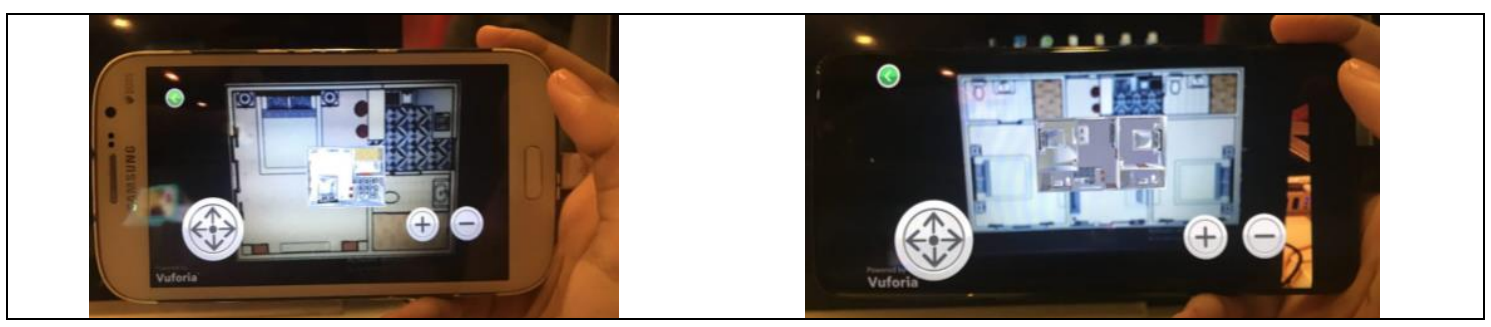

Gambar 14. Hasil Pengujian Fitur Tracking Marker pada Samsung Grand Neo Duos dan Samsung Galaxy S9

Gambar 14 menunjukkan kedua perangkat dapat menampilkan gambar 3-dimensi dengan baik. Waktu yang diperlukan untuk menampilkan gambar 3-dimensi ketika melakukan tracking pada Samsung Grand Neo Duos adalah 8 detik, sedangkan pada Samsung Galaxy S9 4 detik. Perbedaan waktu untuk menampilkan gambar 3-dimensi disebabkan oleh perbedaan spesifikasi kedua perangkat.

Fitur terakhir yang diuji adalah fitur rotate. Fitur rotate berfungsi agar gambar 3-dimensi dapat diputar dalam kemiringan tertentu. Gambar 15 menampilkan hasil pengujian fitur rotate pada kedua perangkat uji.

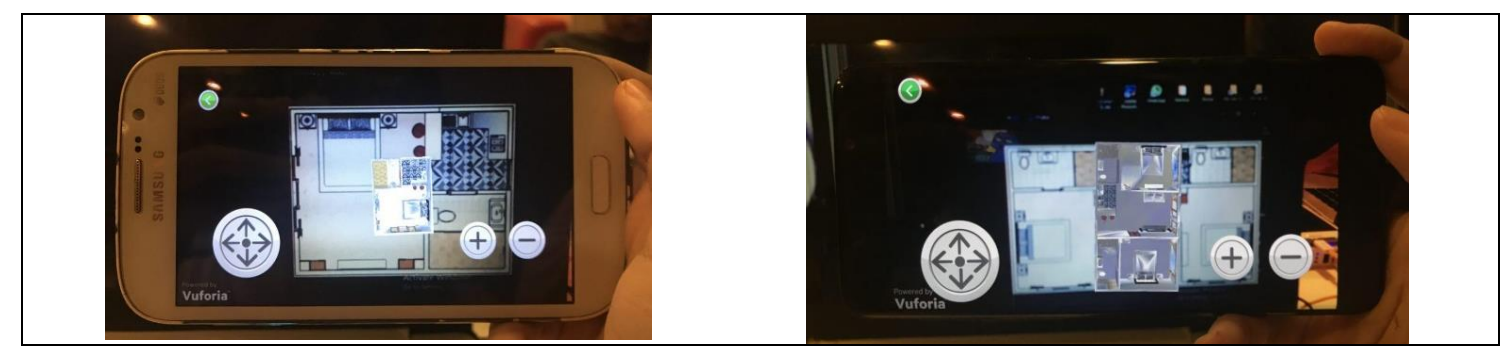

Gambar 15. Hasil Pengujian Fitur Rotate pada Samsung Grand Neo Duos dan Samsung Galaxy S9

Gambar 15 menunjukkan objek 3-dimensi sudah dapat diputar dan telah berfungsi dengan baik pada setiap perangkat. Letak tombol rotate menyesuaikan resolusi layar di masing-masing perangkat uji coba.

\section{Kesimpulan}

Aplikasi augmented reality berbasis Android pada penelitian ini berhasil memvisualisasikan katalog apartemen dengan marker dinamis. Tipe-tipe apartemen yang ada pada katalog divisualisasikan dengan model 3-dimensi sehingga katalog menjadi lebih interaktif. Model 3-dimensi masing-masing dinamakan roomone (marker apartemen tipe satu kamar), roomtwo (marker apartemen tipe dua kamar) dan roomthree (marker apartemen tipe tiga kamar). Aplikasi berhasil menjalankan semua scene dan fitur sesuai dengan fungsinya. Tiga scene yang diujicobakan yaitu scene main menu, about, dan panduan penggunaan. Dua fitur yang diujicobakan adalah fitur tracking marker dan fitur rotate. Fitur tracking marker dan rotate dapat berfungsi pada dua perangkat uji coba.

\section{Daftar Pustaka}

[1] J. A. Sutanto, "Pengaruh Service Quality dan Perceived Value Terhadap Kepuasan dan Loyalitas Konsumen Apartemen di Kota Surabaya," Jurnal Majalah Ekonomi, vol. 18, no. 3, pp. 286-301, 2008.

[2] C. International, "Colliers Quarterly Q1 2017 Jakarta Apartment," 2017.

[3] G. Y. P. Pangestu, N. M. I. M. Mandenni, and N. K. D. Rusjayanthi, "Aplikasi Web Augmented Reality Villa," Merpati, vol. 5, no. 1, pp. 29-40, 2017.

[4] A. F. Waruwu, I. P. A. Bayupati, and I. K. G. Darma Putra, "Augmented Reality Mobile Application of Balinese Hindu Temples: DewataAR," International Journal of Computer Network and Information Security, vol. 7, no. 2, pp. 59-66, 2015.

[5] N. P. S. Franza, A. A. K. Oka Sudana, and K. S. Wibawa, "Application of Basic Balinese Dance Using Augmented Reality on Android," Journal of Theoretical and Applied 
Information Technology, vol. 90, no. 1, pp. 61-66, 2016.

[6] S. H. Liao and Y. J. Chen, "Mining Customer Knowledge for Electronic Catalog Marketing," Expert Systems with Applications, vol. 27, no. 4, pp. 521-532, 2004.

[7] G. Javadian Dehkordi, S. Rezvani, M. Sabbir Rahman, F. Fouladivanda, and S. Faramarzi Jouya, "A Conceptual Study on E-marketing and Its Operation on Firm's Promotion and Understanding Customer's Response," International Journal of Business and Management, vol. 7, no. 19, pp. 114-124, 2012.

[8] S. C. Y. Yuen, G. Yaoyuneyong, and E. Johnson, "Augmented Reality: An Overview and Five Directions for AR in Education," Journal of Educational Technology Development and Exchange, vol. 4, no. 1, pp. 119-140, 2011.

[9] I. G. A. Nugraha, I. K. G. D. Putra, and I. M. Sukarsa, "Rancang Bangun Aplikasi Android AR Museum Bali: Gedung Karangasem dan Gedung Tabanan," Lontar Komputer, vol. 7, no. 2, pp. 93-103, 2016.

[10] I. D. G. W. Dhiyatmika, I. K. G. D. Putra, and N. M. I. M. Mandenni, "Aplikasi Augmented Reality Magic Book Pengenalan Binatang untuk Siswa TK," Lontar Komputer, vol. 6, no. 2, pp. 120-127, 2015.

[11] H. Ling, "Augmented Reality in Reality," IEEE Multimedia, vol. 24, no. 3, pp. 10-15, 2017. 